PAEDAGogia CHRISTIANA

$1 / 25$ (2010) - ISSN 1505-6872

Bogustaw Milerski*

Warszawa

\title{
Myśl dialogiczna w tradycji protestanckiej
}

Geneza współczesnej pedagogiki dialogu jest na ogół postrzegana z perspektywy filozofii Martina Bubera i Franza Rosenzweiga. Niewątpliwie ich dokonania miały fundamentalny wpływ na rozwój tej tradycji myślowej. Filozofia dialogu wyrosła z krytyki tzw. europejskiej filozofii świadomości, której głównymi nurtami była idealistyczna filozofia transcendentalna oraz racjonalistyczna metafizyka. Cechą tych nurtów było przekonanie, że świat ujawnia się na poziomie świadomości w sposób racjonalny i dający się w sposób systematyczny i całościowy opisać w pojęciach. Podstawowym wyznacznikiem filozofii dialogu jest natomiast protest przeciwko idealistycznym uzurpacjom rozumu ludzkiego, dążącego do unifikującego opisu rzeczywistości ludzkiej egzystencji. Drugim ważnym zakorzenieniem filozofii dialogu jest refleksja religijna, w przypadku Bubera i Rosenzweiga - religijne tradycje judaizmu. Należy podkreślić, że na początku XX w. krytyka idealizmu oraz inspiracje religijne legły u podstaw rozwoju myśli dialogicznej nie tylko w tradycji żydowskiej, lecz również katolickiej i protestanckiej. W niniejszym przyczynku postaramy się zrekonstruować podstawowe wyznaczniki dialogiki protestanckiej oraz jej recepcję pedagogiczną. Ograniczymy się przy tym do rozumienia tradycji protestanckiej w kategoriach nurtów wywodzących swoją tożsamość z XVI-wiecznej teologii reformacyjnej.

Rekonstruując protestancką filozofię i teologię dialogu, można wymienić jej reformacyjną genezę oraz dwa współczesne etapy: dialogiki wertykalnej, charakterystycznej dla teologii dialektycznej, oraz dialogiki horyzon-

* Ks. dr hab. Bogusław Milerski, profesor Chrześcijańskiej Akademii Teologicznej i Akademii Pedagogiki Specjalnej w Warszawie, prorektor Chrześcijańskiej Akademii Teologicznej. 
talnej, rozwijanej przez przedstawicieli teologii etycznie zaangażowanego chrześcijaństwa. Z dzisiejszej perspektywy zasadne wydaje się stwierdzenie, że dokonania przedstawicieli tych kierunków teologicznych stanowią główne świadectwo zainteresowania dialogiką. Poniekąd wyczerpali oni także rezerwuar możliwych interpretacji. Stąd też w późniejszej teologii protestanckiej refleksja dialogiczna jest na ogół przywoływana za pośrednictwem opisanych w niniejszym przyczynku klasyków. W tej postaci przeniknęła ona także do protestanckiej pedagogiki religii. Należy również pamiętać, że samo pojęcie dialogu odnosi się nie tylko do swoistej ontologii ludzkiej relacyjności, czym zajmowała się filozofia dialogu, lecz również do teorii komunikacji i porozumienia. Te ostatnie kwestie nie będą jednak przedmiotem prezentowanych rozważań.

\section{Reformacyjna geneza myśli dialogicznej}

Historia myśli dialogicznej w tradycji protestanckiej sięga korzeniami okresu reformacji. Istotą reformacyjnego zwrotu było podważenie znaczenia instancji pośredniczących w relacji pomiędzy człowiekiem i Bogiem. Reformacja uznała tym samym, że relacja ta ma charakter bezpośredni. Bóg i człowiek stoją wobec siebie naprzeciwko, a medium tej relacji jest słowo. Relacja ta nie jest jednak symetryczna. Człowiek nie jest bowiem w stanie nawiązać sam z siebie kontaktu z Bogiem. To Bóg objawia się człowiekowi. Spotkanie z Bogiem objawiającym się w Słowie domaga się od człowieka odpowiedzi i zarazem jednostkowej odpowiedzialności za kształt życia. W tym sensie relacyjność zyskuje wymiar teologiczny i etyczny zarazem.

Wyznacznikiem głównych nurtów reformacji był dystans wobec metafizyki scholastycznej i jej ontologii. W zamian preferowano refleksję biblijna, teologię pisaną historiami wspólnot ludzkich (narodu wybranego, a następnie zborów chrześcijańskich), konkretnych ludzi i wreszcie Boga, który stał się człowiekiem. Bóg takiej teologii był nie tyle „bytem samym” czy też „bytem samym w sobie”, przedmiotem refleksji spekulatywnej, ile przede wszystkim „Bogiem osobowym”, będącym „dla człowieka”, przemawiającym do niego, a w ostateczności objawionym w konkretnej osobie. Teologia reformacyjna jako teologia biblijna rozwijała się w kierunku teologii dylematów egzystencjalnych, teologii Słowa Bożego i teologii spotkania. W wykładni podstawowych kategorii teologicznych akcent był położony na kwestiach egzystencjalnych. $\mathrm{Z}$ tego też względu istoty wiary nie można zredukować do wymiaru poznawczego, do znajomości doktryny czy znajomości historii Jezusa Chrystusa. Wiara zyskiwała bowiem przede wszystkim charakter fiducjalny - polegała na zaufaniu i zawierze- 
niu ${ }^{1}$. Zgodnie z teologią reformacyjna, wiary nie można autorytatywnie zadekretować czy przekazać. Ona jest całościowym aktem egzystencjalnym, podmiotowym i relacyjnym. Ona jest przede wszystkim kwestią osoby i jej wyboru, a nie instytucji.

Kolejnych przesłanek myśli dialogicznej dostarczyło reformacyjne rozumienie Kościoła. Protestantyzm odszedł od wiązania istoty Kościoła z czynnikiem instytucjonalnym. Kościół jest przede wszystkim zgromadzeniem, wspólnotą wszystkich wierzących. Do elementarnego istnienia Kościoła nie tyle jest niezbędna instytucja, ile wspólnotowość i zgodność z Pismem Świętym w kwestiach pryncypialnych. „Dla prawdziwej jedności Kościoła wystarczy zgodność w nauce Ewangelii i udzielaniu sakramentów"2. Za ową zgodność nie jest odpowiedzialne jakieś wąskie gremium, lecz - na mocy tzw. nauki o powszechnym kapłaństwie wszystkich wierzących - ogół członków Kościoła. W tym sensie Kościół zaczął być pojmowany w kategoriach wspólnoty komunikacyjnej, w której dialog stał się istotnym elementem rozumienia rzeczywistości.

Komunikacyjny charakter Kościoła jako wspólnoty ludzi wierzących ukształtował praktykę kultyczną, zwłaszcza rozumienie nabożeństwa ewangelickiego, opisane przez Lutra m.in. w Die deutsche Messe (1526). Celowi temu służyło nie tylko wprowadzenie języków narodowych, lecz również dialogicznej formy odprawiania samego nabożeństwa. Dialogiczne podstawy nabożeństwa zostały jednoznacznie wyrażone przez Lutra w 1544 r. podczas poświęcenia nowo wybudowanego kościoła zamkowego w Torgawie koło Wittenbergi. Rozpoczynając kazanie, stwierdził, że istotą domu Bożego jest rozmowa - Bóg przemawia do człowieka przez swoje Słowo, a człowiek rozmawia z Bogiem przez modlitwę i śpiew pochwalny.

Dialogiczne aspekty teologii i kultu implikowały dialogiczną pedagogię reformacyjna. Ideałem edukacyjnym stała się pobożność rozumna i wymowna (sapiens atque eloquens pietas). Była to zarazem pobożność, która nie mogła być zapożyczona, lecz samodzielnie przeżywana i wyrażana. Ujęcie takie skutkowało nową orientacją dydaktyczną ukierunkowaną na dialog i wyjaśnienie materiału (eksplikację). Stąd też podstawowym materiałem dydaktyki religijnej stały się katechizmy, prezentujące podstawowe kwestie wiary w formie pytan i odpowiedzi. Dialogiczna budowa katechizmów protestanckich dotyczyła nie tylko struktury prezentacji treści dydaktycznych, lecz również wyrażała dialogiczną istotę samej relacji pedagogicznej. Ilustracją takiego podejścia na najbardziej elementarnym poziomie nauczania

${ }^{1}$ Por. Obrona Wyznania augsburskiego, w: Księgi wyznaniowe Kościoła luterańskiego, Bielsko-Biała 1999, s. 178 (art. 4 pkt. 48).

2 Wyznanie augsburskie, w: Księgi wyznaniowe, s. 144 (art. VII). 
może być wypowiedź Marcina Lutra z Małego katechizmu (1529) dotycząca nauki o sakramencie:

Dlatego nie wolno ci ustanawiać tu jakiejś ustawy [...]; przedstaw tylko należycie pożytek i szkodę, potrzebę i przydatność, niebezpieczeństwo i błogosławieństwo tego sakramentu, a przyjdą do niego sami bez twego przymuszania. Jeśli jednak nie przyjda, to pozostaw ich i powiedz im.... Jeżeli [...] z tego robisz przymus i truciznę, to jest twoją winą, że pogardzają sakramentem³

Innymi słowy, pedagogia reformacyjna nie może być formą autorytatywnych nakazów („,nie wolno ustanawiać jakiejś ustawy”), lecz powinna polegać na prezentowaniu aspektów zagadnienia (,przedstaw tylko należycie pożytek i szkodę...”), bez wywierania przymusu (,pozostaw ich”), z jednoczesnym wyrażeniem własnego stanowiska (,powiedz im”). Podstawowym wyznacznikiem pedagogii reformacyjnej staje się więc dialog, którego medium jest słowo, oraz etos wzajemnego uznania - uznania wolności sumienia i suwerenności jednostki.

Konkludując należy podkreślić, że tradycja reformacyjna sformułowała przesłanki, które legły u podstaw współczesnej protestanckiej myśli dialogicznej jako formy refleksji teologicznej i pedagogicznoreligijnej. Ten specyficzny typ refleksji zaczął być uprawiany dopiero w XX w., zwłaszcza na gruncie tzw. teologii dialektycznej oraz etycznie zorientowanej teologii sekularyzacji i teologii politycznej, formułujących koncepcję Boga jako transcendencji etycznej. Teologie te zainspirowały następnie niektórych przedstawicieli protestanckiej pedagogiki religii.

\section{Teologia dialektyczna: prymat dialogiki wertykalnej}

Teologia dialektyczna, zwana także teologią kryzysu bądź teologią Słowa Bożego, była kierunkiem powstałym na gruncie protestantyzmu w niemieckim obszarze językowym w okresie po zakończeniu I wojny światowej. Za jej twórców uznaje się Karola Bartha, Emila Brunnera, Friedricha Gogartena i Eduarda Thurneysena. Głównym forum teologów dialektycznych stało się czasopismo „Zwischen den Zeiten”. Teolodzy dialektyczni krytykowali historyzm i psychologizm teologii liberalnej. W miejsce teologii opierającej się na badaniu materiału historycznego czy empirycznego proponowali teologię wychodzącą od objawienia jako jedynego i krytycznego kryterium każdego namysłu teologicznego. Dlatego też teologia nie powinna opierać się na metafizycznych spekulacjach czy analizach empirycznych, ile wyłącznie na

${ }^{3}$ M. Luter, Mały katechizm, w: Księgi wyznaniowe, s. 43. 
objawieniu samego Boga. Świadomość wiary, jak pisał odkryty przez dialektyków duński filozof i teolog Søeren Kierkegaard, nie wywodzi się z przesłanek empirycznych, i to niezależnie od ich natury - historycznej, kulturowej czy psychicznej. Czynniki te mogą być co najwyżej pobudką dla wiary, ale nigdy jej założeniem konstytutywnym. Wiara rodzi się bowiem w wydarzeniu chwili, kiedy człowiek zostaje postawiony w absolutnym stosunku wobec Absolutu i dzięki objawieniu, mimo nieskończonej różnicy, rozpoznaje siebie wobec Boga. Podkreślając znaczenie transcendencji Boga i jego jakościowej różnicy wobec człowieka i jego świata, przedstawiciele teologii dialektycznej stanęli przed podstawowym dylematem. Jak jest bowiem możliwe spotkanie pomiędzy jakościowo odmiennymi rzeczywistościami?

Teologia dialektyczna była niewątpliwie formą krytycznego osądu doczesności. Osąd ten, wyprowadzany z perspektywy nieuwarunkowanego charakteru objawienia w postaci Słowa Bożego (stąd pojęcie „teologia Słowa Bożego"), dotyczył wszystkich samodzielnych kreacji człowieka i porządków doczesności. W tym sensie teologia stawiała pod znakiem zapytania dokonania człowieka i ujawniała ich kryzys (stąd pojęcie „teologia kryzysu”). Krytycyzm teologiczny w szczególny sposób odnosił się do języka religijnego i sposobów pojmowania Boga. Zwłaszcza w początkowym okresie rozwoju teologii dialektycznej dotyczył on również języka samej teologii. Wypowiedź teologiczna od strony językowej jest również uwarunkowana kulturowo, a tym samym domaga się krytycznego osądu. Człowiek pod wpływem objawienia nie jest w stanie zachować milczenia. Ale każda próba jego wyrażenia, jako teza, pociaga konieczność krytycznej negacji - antytezy (stąd pojęcie „teologia dialektyczna”). Objawiający się Bóg pozostaje przecież ciągle Bogiem, a więc kimś całkowicie innym, i nawet pod postacią Słowa wymyka się „literze”, przynależącej do świata kultury. Pozostanie na tym etapie refleksji groziło więc absolutyzacją różnicy. Tymczasem dialektyka tezy i antytezy domaga się również syntezy. Jedną z ważniejszych dróg poszukiwania owej syntezy stało się oparcie dialektyki teologicznej na fundamencie myśli dialogicznej. Dzięki kategoriom relacyjności osobowego bytu, dialogu, spotkania i obecności dialektycy opisywali możliwość syntezy i punktu styczności pomiędzy jakościowo odmiennymi rzeczywistościami Boga i człowieka. W tym sensie teologia dialektyczna stała się jednym z głównych nurtów prekursorskich wobec współczesnej filozofii i pedagogiki dialogu.

\subsection{Dialogika Karola Bartha}

Dokonania Bartha uprawomocniają jego pozycję jako jednego z najwybitniejszych teologów XX w. Z naszej perspektywy należy podkreślić, że zwłaszcza w pierwszym okresie swojej twórczości zamarkował on potencjał 
refleksji dialogicznej. Barth opublikował wówczas Der Römerbrief-List do Rzymian, dzieło, które stało się manifestem programowym teologii dialektycznej. Warto również zauważyć, że pierwsze wydanie książki przypadło na rok 1919, a więc poprzedziło czasowo fundamentalne dla filozofii i teologii dialogu rozprawy. Gwiazda zbawienia Franza Rosenzweiga ukazała się bowiem w 1921 r., Ja i Ty Martina Bubera - w 1923 r., a Stowo i realności duchowe. Fragmenty pneumatologiczne Ferdynanda Ebnera - w 1921 r.

Za podstawę teologicznych wykładni Bartha przyjmuje się drugie, w sposób istotny zmodyfikowane wydanie Listu do Rzymian (1922). Był to traktat $\mathrm{w}$ formie komentarza teologicznego do tytułowego listu apostoła Pawła. W dziele tym zostały wyartykułowane podstawowe tezy teologii dialektycznej, przede wszystkim radykalna, jakościowa różnica między Bogiem i człowiekiem. W przedmowie do drugiego wydania dzieła Barth pisał: „Jeżeli mam jakikolwiek 'system', to polega on na nieustannym dostrzeganiu tego, co Kierkegaard nazwał 'nieskończona, jakościową różnicą' czasu i wieczności, i to zarówno w pozytywnym, jak i negatywnym znaczeniu. Relacja 'takiego' Boga do 'takiego' człowieka, relacja ‘takiego' człowieka do 'takiego' Boga jest dla mnie tematem Biblii i sumą filozofii w jednym"4. Dla zobrazowania tego stanu rzeczy Barth użył figury retorycznej będącej w istocie tautologią: „Bóg jest Bogiem”s. Wyrażenie będące tautologią samo w sobie nie rozszerza wiedzy. Jednak odniesienie tej tautologii do prawdy o człowieku, który przecież nie jest Bogiem, stawało się nośnikiem znaczenia teologicznego. Można wręcz powiedzieć, że w domyśle Barth konfrontował ze sobą dwie tautologie: „Bóg jest Bogiem” i „człowiek jest człowiekiem”. Dzięki takiemu zabiegowi retorycznemu chciał on podkreślić wagę przekonania, że Bóg jest rzeczywiście Bogiem, a nie człowiekiem, i zarazem, że człowiek jest tylko człowiekiem, a nie Bogiem. Pomiędzy Bogiem i światem rozciaga się jakościowa różnica (diastaza). Różnica ta nie ma charakteru ilościowego, lecz jakościowy. Nie jest więc możliwe uprawianie teologii w oparciu o ideę analogii ontycznej. Innymi słowy, na podstawie analizy bytu naturalnego, jego struktury, aspektów psychologicznych czy społecznych nie można przez analogię formułować twierdzeń dotyczących Boga. Barth odrzucił więc myślenie teologiczne, którego punktem wyjścia miałaby być analiza doczesności (koncepcja analogii). Droga taka - zdaniem Bartha - została już skrytykowana w biblijnej opowieść o upadku człowieka w grzech ${ }^{6}$. Oto człowiek uległ własnej hybris i wdał się w spekulację ,czy aby Bóg powiedział”. Człowiek, miast być posłusznym Bogu, a więc wsłuchanym w jego Słowo,

\footnotetext{
${ }^{4}$ K. Barth, Der Römerbrief (1922), Zürich 1989, s. XX.

5 Tamże, s. XXI.

${ }^{6}$ Tamże, s. 244 i następne.
} 
uprzedmiotowił Boga, uczynił z niego przedmiot własnego poznania. Tego typu spekulacja stała się pierwowzorem wypowiedzi religijnych i fałszywie pojętej teologii, gdy tymczasem prawdziwa teologia jako „teo-logia” (nauka, słowo samego Boga) może opierać się wyłącznie na objawieniu. $Z$ tej perspektywy Barth przeprowadził krytykę religii. W jego przekonaniu religijne wyobrażenia, w tym poglądy o Bogu, są produktem ludzkiej psychiki i jako takie powinny podlegać krytyce i negacji teologicznej. Do Boga nie prowadzą bowiem żadne religijne mosty. „On jest tym, który jest ponad nami, ponad najwyższymi i najgłębszymi uczuciami, dążeniami, intuicjami, ponad produktami ludzkiego ducha"7.

Przyjmując perspektywę jakościowej różnicy pomiędzy symbolicznym niebem i ziemią, Barth był przekonany, że ową różnice jest w stanie pokonać wyłącznie Bóg. Objawienie jako przekroczenie jakościowej różnicy ma konkretną postać - dokonuje się pod postacią Słowa. Bóg przemawia w swoim Słowie (dominus dixit). Dzięki objawieniu w Słowie Bóg oddalony (deus absconditus) staje się Bogiem objawionym (deus revelatus), a więc Bogiem ujawniającym się człowiekowi w świecie doczesnym. Objawienie to jest skierowane na jednostkę i może na nią oddziaływać. Zarazem jednak nie może zostać zamknięte w doczesności i wyrażone za pomocą języka ludzkiego - pojęciowości przynależącej do tego świata. W ujęciu Bartha objawienie jest bowiem chwila, jest wydarzeniem ahistorycznym, w którym absolutnie Inny ujawnia się człowiekowi, w którym wieczność zawiesza doczesność. W konkretnej chwili, określanej w teologii pojęciem kairos, zostaje zawieszony czas jako chronos. Chwila staje się momentem odsłonięcia się wieczności, kiedy człowiek może rozpoznać swój związek z Bogiem

Nie wdając się w szczegóły teologii Bartha, w analizę jej dalszego rozwoju, którego zwieńczeniem była wielotomowa Dogmatyka kościelna, a tym bardziej w kwestie interpretacji jego poglądów, odnotujmy jedynie dialogiczną strukturę jego teologii. Była to jednak dialogika specyficzna. Można ją określić mianem wertykalnej. Odnosiła się ona bowiem do relacji pomiędzy Bogiem i człowiekiem. Podobnie do innych koncepcji dialogicznych zakładała ona osobową suwerenność i wzajemną bytową transcendencję podmiotów relacji, w tym wypadku - Boga i człowieka. Uznawała ona również słowo (Słowo Boże) za podstawowe medium tej relacji. Jednak sama relacja nie tyle polegała na dialogu jako wymianie słów, ile przede wszystkim $\mathrm{z}$ jednej strony - na ujawnianiu się Boga w Słowie, z drugiej natomiast - na posłuszeństwie człowieka i wsłuchaniu w kierowane do niego Słowo. Mimo powyższego zastrzeżenia należy docenić wkład Bartha w rozwój myśli dia-

\footnotetext{
7 Tenże, Dogmatik im Grundriß, Zürich 1987, s. 41.

8 Tenże, Der Römerbrief (1922), s. 523.
} 
logicznej. Dialogika wertykalna stała się nie tylko opisem relacji między Bogiem i człowiekiem, lecz również istotą refleksji teologicznej. Teologia nie jest naukową konceptualizacją świadomości religijnej osób wierzących. W ujęciu Bartha teologia jest o tyle możliwa, o ile Bóg przemawia. W tym sensie nie może ona być systemowa, idealistyczna i unifikująca, lecz wywodząca się i podkreślająca egzystencjalne znaczenie jednostkowych wydarzeń spotkania ze Słowem i Tym, który je wypowiada.

Przypisując dialogice wertykalnej centralne miejsce w teologii Bartha, należy zaznaczyć, że w kategoriach dialogicznych starał się on opisać nie tylko relację człowieka do Boga, lecz również istotę wspólnoty ludzkiej. W tym sensie markował konieczność uwzględnienia w teologii dialogiki horyzontalnej. Barth był przekonany, że chrześcijaństwo nie jest sumą zatomizowanych jednostek, lecz opiera się na uznaniu fundamentalnego znaczenia wspólnoty. Pogląd taki wyrażają m.in. idee ludu Bożego, zboru czy Kościoła. Zarazem jednak wspólnota nie powinna być traktowana w kategoriach rzeczywistości, która występowałaby przed jednostką jako jakiś ogół bądź abstrakt. Wspólnota to nie totalność, lecz zawsze konkretni ludzie, spotykający się w jednostkowości i indywidualności własnej egzystencji. Wspólnota „nie oznacza zniesienia, ograniczenia czy wytarcia niepowtarzalności jednostki" ". $\mathrm{Z}$ tego też względu w dalszych partiach tekstu Barth nie tylko ujmował stosunek człowieka do Boga w kategoriach dialogicznych, lecz także wpisywał ów stosunek w dialogiczną relację jednostki do drugiego człowieka. Pisząc o Bogu jako o Ty, które wymyka się naoczności, zauważał, że często owo boskie Ty spotyka nas ,pod postacią bliźniego, który 'wpadł w ręce oprawców'. Jeżeli nie słyszę tutaj pytania i odpowiedzi, jeżeli słyszę tutaj jedynie głos innego, a nie - w jego głosie - głos Jedynego, to nie słyszę go w ogóle"10. Stwierdzenie to zdaje się anonsować koncepcję fenomenologii obecności Boga jako transcendencji etycznej.

\subsection{Dialogika Emila Brunnera}

Cechą charakterystyczną twórczości teologicznej Brunnera było m.in. ciagłe konfrontowanie teologii z filozofią. Filozoficzne analizy kondycji ludzkiej stanowiły bowiem przesłankę dla poszukiwań teologicznych odpowiedzi. Powyższe stwierdzenie należy właściwie zrozumieć. Zdaniem Brunnera, Boże objawienie, które poświadcza teologia, nie potrzebuje filozoficznego uprawomocnienia. $\mathrm{Z}$ drugiej jednak strony, objawienie to ma

\footnotetext{
9 Tamże, s. 467.

${ }^{10}$ Tamże, s. 521.
} 
konkretnego adresata - człowieka. W tym sensie zadaniem teologii jest ukazanie egzystencjalnego znaczenia objawienia Bożego.

Brunner w duchu teologii dialektycznej podkreślał jakościową różnicę pomiędzy doczesnością i wiecznością. Z tej perspektywy powtarzane przez niektórych teologów stwierdzenie: est Deus in nobis, pisał Brunner w swojej późnej rozprawie poświęconej egzystencjalizmowi chrześcijańskiemu, jest całkowitym nieporozumieniem. Bóg, owszem, może dawać się poznać człowiekowi i ponownie nawiązywać z nim społeczność, ale nie jest „w” człowieku. Prawda jest bowiem nie „w nas” (in nobis), lecz ,poza nami” (extra nos). Rozróżnienie to stanowiło, jego zdaniem, jeden z najbardziej istotnych wyznaczników teologii reformacyjnej. Z tego też względu od samego początku Brunner był krytykiem mistyki, której przeciwstawiał ewangelicką teologię Słowa. W przyczynku Die Mystik und das Wort (1924), określając stosunek teologii do mistyki, napisał wprost: ,albo mistyka, albo Słowo"11. Chrześcijaństwo, o czym był przekonany, nie powinno się opierać na wewnętrznym i subiektywnym przeżyciu jedności z Bogiem, lecz na przyjęciu objawienia, którego wyłącznym medium jest zewnętrzne wobec człowieka, a przez to obiektywne Słowo Boże - Słowo, które ciałem się stało.

W latach 30. XX w. Brunner, inspirując się dokonaniami Ferdynanda Ebnera i Martina Bubera, zreinterpretował swoją teologię w kategoriach filozofii i teologii dialogu. Dał temu wyraz w wykładach prowadzonych w 1937 r. w Uppsali, wydanych rok później jako Wahrheit als Begegnung (Prawda jako spotkanie). Książka ta stała się programową prezentacją głównych tez jego koncepcji. Przedstawiona w niej dialogiczna struktura bytu ludzkiego stała się kolejnym punktem styczności pomiędzy Bogiem a człowiekiem. Brunner twierdził, że ludzkie „Ja” konstytuuje się zawsze w relacji z „Ty”, w wymiarze religijnym - z boskim ,Ty”. Z tego też względu człowieka nie można zrozumieć poprzez odwołanie się do popularnych wówczas tradycji filozoficznych: ewolucjonizmu (Darwin), idealizmu subiektywnego (Kant) czy idealizmu obiektywnego (Hegel). Prawda o kondycji humanum została tymczasem objawiona w Biblii, która ujmuje człowieka nie tyle w kategoriach przedmiotu bądź podmiotu poznania, który byłby w stanie zrozumieć się sam z siebie, ile przede wszystkim, jak pisał Brunner, jako ,aktualność responsoryczną", tzn. jako byt dziejowy, aktualizujący się w dialogu (wezwany do odpowiedzi i odpowiedzialności, co wyraża łacińskie pojęcie respondentis $)^{12}$. Dlatego do opisu objawienia i wiary chrześcijańskiej nie przystaje przejęty z filozofii poznania schemat podmiot-przedmiot. Prawdziwa

${ }^{11}$ E. Brunner, Die Mystik und das Wort, w: J. Moltmann (red.), Anfänge der dialektischen Theologie: Karl Barth, Heinrich Barth, Emil Brunner, München 1985, s. 283.

12 Tenże, Wahrheit als Begegnung, Zürich, Stuttgart 1963, s. 43. 
wiara nie jest bowiem aktem poznawczym, lecz egzystencjalnym, dokonującym się w wydarzeniu spotkania.

Brunner podkreślał, że objawienie biblijne nie opiera się na pojęciach Boga-w-sobie i człowieka-w-sobie, lecz ma charakter relacyjny - odnosi się do stosunku Boga do człowieka i człowieka do Boga. Według Pisma Świętego Bóg nie chce być pojmowany jako jakiś absolut, lecz jako istota zwrócona ku człowiekowi. Podobnie, biblijna wizja człowieka nie podkreśla jego autonomii, lecz bycie w relacji do Boga. Obrazy te zyskały spełnienie w Jezusie Chrystusie, którego osoba jest uprawomocnieniem dialogicznego charakteru zarówno Boga, jak i człowieka. Brunner był przekonany, że uznając dialogiczność i możliwość spotkania za istotę relacji pomiędzy Bogiem i człowiekiem, teologia nie może być formą teoretycznej, abstrakcyjnej konceptualizacji, lecz musi być zakorzeniona w egzystencji i historii. Dialog i spotkanie są bowiem zawsze konkretne ${ }^{13}$.

Powyższe rozumienie Brunner powtórzył w obszernym dziele z $1941 \mathrm{r}$. Offenbarung und Vernunft (Objawienie i rozum). Twierdził tam, że objawienie biblijne jest nieuwarunkowanym ujawnieniem się tego, co jest ostatecznie zakryte. Objawienie pochodzi bowiem od rzeczywistości, która jako taka nie jest dostępna człowiekowi. W tym sensie objawienie tajemnicy pozostaje tajemnicą. Ona nie jest bowiem dostępna poznaniu ludzkiemu. Tajemnicy tej nie można jednak utożsamić z pojęciem Absolutnie-Innego. Pojęcie takie jest nie tylko czystą abstrakcja, lecz przede wszystkim jest obce tradycji biblijnej. Biblia nie mówi bowiem o abstrakcyjnej tajemnicy i abstrakcyjnej transcendencji, lecz o Tym, który jest tajemnicą i transcendencją. Prawda objawienia biblijnego nie ma więc charakteru teoriopoznawczego, lecz osobowy. Dlatego, zdaniem Brunnera, należy odrzucić utożsamianie objawienia z zarówno komunikowaniem wiedzy, jak i egzystencjalnym wstrząsem wobec niezrozumiałej, abstrakcyjnej rzeczywistości tego, co absolutne. Objawienie jest bowiem ukazaniem się Bożego „Ja” („I przemówił Pan do...”) jako ludzkiego naprzeciwko. Nie można go więc sprowadzić ani do nauki czy dogmatu, ani do abstraktu. Brunner ujął więc objawienie nie w kategoriach przedmiotowo-poznawczych, ile z perspektywy fenomenologii obecności i spotkania. Objawienie dokonuje się w spotkaniu Boga z człowiekiem. W tym sensie ma charakter dialogiczny, egzystencjalny i dziejowy. W konsekwencji wiara wiąże się nie tyle z poznaniem, ile z zaufaniem i zawierzeniem.

Brunner, podkreślając fundamentalne znaczenie spotkania, zróżnicował swoje stanowisko wobec koncepcji najwybitniejszych teologów ewangelickich tamtego okresu, m.in. Bartha i Bultmanna. W drugim wydaniu Wahrheit als Begegnung (1963) obu teologom przedstawił zarzut dewaluacji spo-

13 Tamże, s. 88. 
tkania jako podstawowej kategorii biblijnej i teologicznej ${ }^{14}$. Brunner wyraził tym samym podstawową intencję nowoczesnej dialogiki. Teologia i filozofia dialogu powinny być zarazem teologią i filozofią spotkania. Istotą dialogu jest bowiem nie tyle wymiana komunikatów, ile spotkanie bytów. Spotkanie to wymyka się racjonalnemu opisowi, a jednocześnie jest czymś realnie doświadczanym i konstytutywnym dla egzystencji człowieka. Ono jest podstawową przesłanką odnowy życia, zmieniając nie tylko sposób myślenia człowieka, lecz również jego bytowania w świecie.

\subsection{Dialogika Friedricha Gogartena}

Jednym z pierwszych świadectw dialektycznych przekonań Gogartena była niewielka monografia z 1921 r. Die religiöse Entscheidung (Decyzja religijna). W późniejszym okresie opracował on klasyczne rozprawy z zakresu etyki politycznej oraz teologii świadomej wyzwań sekularyzacji. Ważnym kluczem interpretacyjnym rzeczywistości wiary stała się dla Gogartena myśl dialogiczna. Jej istotę zarysował już na początku lat 20 . XX w. w przyczynku Wspólnota czy zbór? (1923) ${ }^{15}$. W moim przekonaniu jest to zasadniczy tekst z zakresu myśli dialogicznej, którego tematyka dotyczy fundamentalnej kwestii konstrukcji porządku społecznego i relacji pomiędzy społeczeństwem i jednostka. Kwestie te stały się jednym z najważniejszych tematów katolickiej filozofii i pedagogiki personalistycznej. Tutaj natomiast otrzymujemy ich oryginalną wykładnię z perspektywy protestanckiej.

Gogarten rozpoczął swoje wywody od stwierdzenia, że z dzisiejszej, nowoczesnej perspektywy wspólnota jest formą życia społecznego, opierającą się na uznaniu indywidualności jednostek i ich woli, na procesie uświadomienia jednostek i ich zgody na kształt życia społecznego. Problem polega jednak na tym, że z ówczesnej perspektywy, a jest to początkowy okres Republiki Weimarskiej, społeczeństwo chwieje się w swych podstawach. Stąd zasadne jawi się pytanie nie tylko o rozumienie życia wspólnotowego, lecz również o status jednostki i spajającego różne jednostki autorytetu. Gogarten polemizował z propozycją Emila Fuchsa, który założył, że spoiwem społeczeństwa może być dążenie do prawdy i prawdziwości. Gogarten ukazał sprzeczność takiego myślenia. Twierdził, że nie można czynić miary z dążenia do prawdziwości, nie zakładając przy tym istnienia prawdy. W tym sensie, aby koncepcja Fuchsa była niesprzeczna, musi on założyć istnienie prawdy. Tyle tylko że w myśleniu indywidualistycznym prawda nie przeja-

\footnotetext{
14 Tamże, s. 45-53.

${ }^{15}$ F. Gogarten, Gemeinschaft oder Gemeinde?, w: J. Moltmann (red.), dz. cyt., s. 153-171.
} 
wia się jako „to, co naprzeciwko”, lecz ujawnia się jako podstawa poznania i oglądu rzeczywistości.

Jeżeli w ujęciu indywidualistycznym jednostka w swoim indywidualnym bycie jest prawda, jeżeli w swoim poznawaniu, o ile jest to poznanie osobowe, sama rozpoznaje prawdę, jeżeli w swoim oglądzie, o ile jest to ogląd pierwotny i twórczy, w ostateczności to prawda sama postrzega rzeczywistość, to prawda nigdy nie może być tym, co naprzeciwko, czymś poza jednostka, czymś, co może być rozpoznawane i postrzegane ${ }^{16}$.

Ujęcie indywidualistyczne nie traktuje więc prawdy jako czegoś „naprzeciwko", lecz jako podstawę poznania ludzkiego. Prawda, będąca podstawa poznania, nie jest zarazem przedmiotem tego poznania. Ona staje się fundamentem ludzkiego Ja. Nie jest ona jednak „,czymś” w Ja, lecz staje się samym Ja. W ujęciu indywidualistycznym, zdaniem Gogartena, Ja staje się w ostateczności uosobieniem prawdy. W takim ujęciu podstawowym zadaniem staje się odkrywanie przez jednostkę samej siebie - uświadomienie podstaw własnego Ja. Zakłada się zarazem, że odkrywając własne Ja, prawdę jako podstawę własnej konstytucji jednostkowej, poszczególne jednostki odkrywają zarazem podstawę życia społecznego. O ile bowiem życie jednostkowe jest zindywidualizowane, o tyle podstawa tego życia jest wspólna i uniwersalna. Jej odkrycie staje się więc drogą do budowania wspólnoty i życia społecznego.
Abym mógł otworzyć się na drugie Ty w jego Ja, w jego indywidualności i swo- istości, które dla mnie jest tak odległe, jak ziemia wobec nieba, musiałbym nic innego nie chcieć, aniżeli przeżyć i ująć samego siebie we własnym najgłęb- szym jestestwie. W tym otwarciu na samego siebie czyniłbym dostępnym nie tylko własne Ja, lecz również otwierałbym własne Ja na innego, ujmowałbym czyste, wieczne Ja boskości we współbrzmieniu z moim Ja i Ja innego ${ }^{17}$.

Gogarten sformułował pytanie dotyczące tożsamości dwóch zdań: indywidualistycznego „Ja jestem Ja” i biblijnego „Jestem, który jestem”. W jego ujęciu, indywidualiści, idealiści i mistycy zakładają tożsamość obu twierdzeń. Podstawą ich jednostkowego, a zarazem wspólnotowego bytu jest Ten, który mówi ,jestem alfą i omegą, początkiem i końcem, tym, który był, jest i będzie”. Czy jednak Ten, który określa się mianem „Jestem, który jestem", może być rzeczywiście metafizyczną podstawą jednostkowego

\footnotetext{
${ }^{16}$ Tamże, s. 159.

17 Tamże, s. 163.
} 
i społecznego bytu? Zdaniem Gogartena, prawda o człowieku nie zasadza się na przekonaniu o boskości jako fundamencie bytu, ale wyraża się w biblijnym wołaniu: „Boże, bądź miłościw mnie grzesznemu!" dotyczące kondycji ludzkiej, nie tyle wzniesionej na metafizycznej skale, ile pozbawionej swych metafizycznych fundamentów. Bóg nie jest bowiem „Ja dla ludzkiego Ja", lecz radykalnym naprzeciwko bytu ludzkiego. Bóg jest „Ty dla ludzkiego Ja”.

Gdy pojawia się Ty, wymykające się każdej próbie przekształcenia w Ja, gmach indywidualizmu rozpada się, a wspólnota indywidualistyczna zaczyna jawić się jako fantom [...]. Owo Ty ukazuje się w tym samym momencie, w którym Ja rozpoznaje, że nie jest właściwą i jedyną rzeczywistością. Kiedy rozpoznaje, że świat jest podzielony na Ja i $\mathrm{Ty}^{19}$.

Podział na Ja i Ty ma wymiar zarówno horyzontalny, jak i wertykalny. $\mathrm{W}$ wymiarze horyzontalnym oznacza uznanie różnicy za podstawową cechę życia społecznego. Właśnie dlatego, że żyjemy w świecie odrębnych osób, w świecie jednostkowych Ja i Ty, życie wspólnotowe nigdy nie może zasadzać się na bezpośredniości relacji międzyludzkich. Pomiędzy Ja i Ty istnieje istotowa różnica. $Z$ tego względu przesłanek życia społecznego nie należy poszukiwać w kategoriach metafizycznej podstawy ontycznej jako swoistej jedni. Przesłanki życia społecznego znajdują się poza ludzkimi bytami, one są extra nos (poza nami). Tylko orientując się na zewnątrz można ustanowić spoiwo ludzkiej wspólnoty. Pytanie o spoiwo jest dla Gogartena pytaniem o zewnętrzny względem człowieka autorytet. Autorytet nie może być jednak dogmatem, gdyż - podobnie jak to miało miejsce w przypadku metafizycznej jedni - unifikowałby życie ludzkie.

Autorytetem może być jedynie Boże Ty [...]. Ty Boga nigdy nie stanie się naszym Ja, i to mimo Angelusa Silesiusa czy też - co bardziej znaczące - mimo Eckharta. Pozostaje Boże Ty, odległe od nas, obce, nieujmowalne, jak każde inne Ty. Tylko jeszcze bardziej odległe, bardziej obce i tym bardziej niemożliwe do ujęcia, gdyż jest to Ty wiecznego Boga. Będziemy jednak zadawać pytanie: jeżeli między Ja i Ty, między ludzkim Ja i Bożym Ty tak się rzeczy mają, jak może człowiek cokolwiek wiedzieć o Bogu? Odpowiedź może być jedna: tylko dlatego, że Bóg sam się ujawnia. I jeżeli nie chce się popaść ponownie w indywidualizm, należy uznać, że Boży przekaz jest rzeczywistym przekazem, a nie jakimś platońsko-idealistycznym przypomnieniem. Bóg pozostaje

\footnotetext{
18 Tamże, s. 163.

19 Tamże, s. 165.
} 
Ty i w żadnym wypadku nie daje się sprowadzić do Ja. Pomiędzy Bogiem i człowiekiem nie istnieje unio mystica [...]. Pozostaje więc jedynie wsłuchanie się w Boże Słowo. Słowo jest bowiem jedyną formą powiadomienia pomiędzy Ja i $\mathrm{Ty}^{20}$.

Zdaniem Gogartena taką strukturę ma zbór, który może stać się wzorem życia wspólnotowego. Zewnętrzny autorytet, który stanowi podstawę istnienia zboru, nie unifikuje i nie dogmatyzuje ludzkiego myślenia i działania w ramach wspólnoty. On gwarantuje indywidualność i wolność, a zarazem wzywa do nieustannej interpretacji i odpowiedzialności. Tworzy zarazem pośrednią (a nie bezpośrednią) więź między poszczególnymi podmiotami życia społecznego, między Ja i Ty. Gogartenowi udało się tym samym powiązać wertykalną dialogikę teologii dialektycznej z problematyką horyzontalnych stosunków międzyludzkich. Cięgle była to jednak dialogika uznająca prymarny charakter orientacji wertykalnej dla opisu relacji Ja i Ty w jej wymiarze teologicznym i antropologicznym.

\section{Teologia etycznie zaangażowanego chrześcijaństwa: prymat dialogiki horyzontalnej}

Na gruncie protestantyzmu sformułowano koncepcje, których wspólnym mianownikiem było dążenie do proklamacji chrześcijaństwa etycznie zaangażowanego. Punktem ich wyjścia była konfrontacja $\mathrm{z}$ wyzwaniami sekularyzacji oraz emancypacji człowieka. Przykładem takiej refleksji sa teologie bezreligijnego chrześcijaństwa Dietricha Bonhoeffera oraz wiary ateistycznej Dorothee Sölle.

W dużym uproszczeniu można stwierdzić, że jednym z rezultatów recepcji procesów sekularyzacyjnych oraz - co należy dodać - pamięci wojny było powstanie tzw. teologii śmierci Boga, głoszącej nie tyle śmierć samego Boga, ile śmierć pojęcia „Bóg”, a tym samym nieadekwatność języka religijnego do opisu ludzkiej egzystencji. Cechą tej teologii było więc dążenie do odnowienia języka orędzia chrześcijańskiego. W pewnym uproszczeniu można stwierdzić, że proponowano trzy kierunki rozwiązań. W pierwszym przypadku język teologii ujmowano jako język symbolu, wskazujący na nieuwarunkowaną podstawę bytu ludzkiego (np. na wzór Paula Tillicha), w drugim jako język nadziei eschatologicznej (np. na wzór Jürgena Moltmanna), a w trzecim jako język etycznej odpowiedzialności. Przykładem trzeciej

${ }^{20}$ Tamże, s. 167-168. W punkcie tym Gogarten odwołał się bezpośrednio do dokonań F. Ebnera zaprezentowanych w pracy Stowo i realności duchowe. Fragmenty pneumatologiczne. 
drogi są dokonania wymienionych powyżej Bonhoeffera i Sölle. Swoje koncepcje osadzili oni w dialogicznej tradycji intelektualnej, proponując nie tylko oryginalne odczytanie orędzia chrześcijańskiego, lecz również wnosząc wkład w rozwój filozofii i teologii dialogu.

Dialogika Bonhoeffera i Sölle była dialogiką horyzontalną. Ich dokonania można zarazem uznać za apogeum zainteresowania filozofią i teologią dialogu. Z nowszych prób reinterpretacji dialogicznego wymiaru ludzkiej egzystencji można przywołać koncepcję Hermanna Timma, monachijskiego filozofa i teologa. Refleksję dialogiczną umieścił on z jednej strony w kontekście pneumatologii teologicznej i filozofii mowy, dla których inspiracji poszukiwał $w$ niemieckim romantyzmie i idealizmie, a także w hermeneutyce współczesnej, z drugiej natomiast w perspektywie tzw. nowej fenomenologii, której stał się jednym z prekursorów, ukazując możliwości całościowego doświadczania rzeczywistości ${ }^{21}$.

\subsection{Dialogika Dietricha Bonhoeffera}

Ilustracją wielowątkowych inspiracji filozofii dialogu, tworzonej w latach dwudziestych XX w., może być dysertacja doktorska Bonhoeffera z 1927 r. Sanctorum Communio. Studium dogmatyczne socjologii Kościoła (opublikowana 1930) ${ }^{22}$. W pracy tej Bonhoeffer rozwiną podstawowe kategorie filozofii dialogu. Znamienne jest przy tym, że w swoich wywodach - czego dowodzi krytyczna edycja tekstu - odwoływał się do Emanuela Hirscha, Eberharda Grisebacha, Theodora Litta i wspomnianych uprzednio Bartha i Gogartena. Inspirował się ich krytyką myślenia idealistycznego, dowartościowaniem aspektów egzystencjalnych, ujęciem relacji pomiędzy jednostką a społeczeństwem i wreszcie samą dialogiką jako sposobem refleksji filozoficznej i teologicznej. W rozdziale poświęconym chrześcijańskiemu pojęciu osoby Bonhoeffer pisał:

Gdy nazywam jednostkę konkretnym Ja, drugi jest konkretnym Ty [...] Inny może zostać doświadczony przez Ja wyłącznie jako Ty [...]. Moje Ja jako forma Ty może zostać doświadczone wyłącznie przez inne Ja, moje Ja jako forma $\mathrm{Ja}$ - tylko przeze mnie; tak więc nigdy forma Ja nie będzie bezpośrednio dana

${ }^{21}$ H. Timm, Von Angesicht zu Angesicht. Sprachmorphische Antropologie, Gütersloh 1992.

${ }^{22}$ D. Bonhoeffer, Sanctorum Communio. Eine dogmatische Untersuchung zur Soziologie der Kirche, oprac. J. von Soosten, Berlin 1987 (=München 1986; tom 1 w ramach 16-tomowej edycji dzieł D. Bonhoeffera - Dietrich Bonhoeffer Werke = DBW). 
w przeżyciu Ty [...]. Forma Ty może zostać zdefiniowana poprzez drugiego, który stawia mnie w sytuacji wyboru etycznego. Dzięki kategorii Ja-Ty jako podstawowej relacji chrześcijańskiej pryncypialnie wykraczamy poza teoriopoznawczą relację podmiot-przedmiot. [...] To, czy drugi jest Ja w znaczeniu relacji Ja-Ty, jest dla mnie niezbadane. [...] Wyłącznie w oparciu o Ty powstaje osoba, i właśnie dlatego pozostaje ona w pełnej izolacji. W swojej niepowtarzalności zasadniczo odróżnia i oddziela się od innych osób. Osoba nie może drugiej osoby poznać, może ją jedynie uznać, w nią wierzyć23.

W podsumowaniu rozdziału konkludował: „Nie istnieje przezwyciężenie osoby przez jakiegoś apersonalnego ducha, nie istnieje jakaś jedność, która znosiłaby osobową wielość. Podstawową kategorią społeczną jest relacja Ja-Ty. Ty drugiego człowieka jest boskim Ty"24. Innymi słowy, Bonhoeffer w swojej wczesnej pracy zrekapitulował podstawowe twierdzenia filozofii dialogu. Był przekonany, że doświadczenie drugiego nie daje się porównać z doświadczeniem rzeczy. Spotkanie Ja z Ty nie powinno być sprowadzane do relacji teoriopoznawczej bądź przedmiotowej. Drugiego człowieka nie można poznać ani posiąść niczym przedmiotu, a jedynie przeżywać jako konkretne i niepowtarzalne Ty. Owo Ty jest jednak z założenia niezbadane poznawczo. Drugi człowiek jest bowiem istotą zatajoną, która jawi się jako pewnego rodzaju transcendencja. Dlatego należy porzucić kategorie logiczne, epistemologiczne i ontologiczne. Tylko język etyki jest w stanie oddać ów dialogiczny wymiar egzystencji. Ujęcie takie w konsekwencji prowadziło do etycznej reorientacji teologii, czemu dał najpełniejszy wyraz w listach i zapiskach więziennych Widerstand und Ergebung, formułując ideę etycznie zorientowanego bezreligijnego chrześcijaństwa ${ }^{25}$.

W listach i zapiskach więziennych Bonhoeffer krytycznie odniósł się do zjawiska religii. Istotny wpływ na jego podejście wywarły inspiracje filozoficzną krytyką religii Ludwika Feuerbacha, Karola Marksa czy Fryderyka Nietzschego, a z perspektywy teologicznej - Karola Bartha. Bonhoeffer powiązał przekonania krytyków religii z doświadczeniem utraty znaczenia i wiarygodności orędzia chrześcijańskiego, a w konsekwencji - chrześcijaństwa jako takiego. ,Tym, co mnie nieustannie porusza, jest pytanie, czym właściwie jest chrześcijaństwo i kim właściwie jest Chrystus dla nas dzisiaj?"26

${ }^{23}$ Tamże, s. 31-32.

${ }^{24}$ Tamże, s. 33.

${ }^{25}$ Tenże, Widerstand und Ergebung. Briefe und Aufzeichnungen aus der Haft, oprac. Chr. Gremmels, E. Bethge, R. Bethge, Chr. Kaiser, Gütersloh 1998 (tom 8 w ramach 16-tomowej krytycznej edycji dzieł: Dietrich Bonhoeffer Werke; 1 „niekrytyczne“ wyd. Widerstand und Ergebung-1951).

${ }^{26}$ Tamże, s. 402. 
Odpowiedź na to pytanie jest tym bardziej trudna, iż dewaluacja religii wyraża nowy stan świadomości społecznej.

Wykraczamy naprzeciwko czasów całkowicie bezreligijnych... Nasze 1900letnie zwiastowanie chrześcijańskie i teologia opierają się na religijnym a priori człowieka. Chrześcijaństwo było zawsze traktowane jako jedna z form religii (być może prawdziwa). Jeżeli jednak okaże się pewnego dnia, że owe a priori po prostu nie istnieje, lecz było zwykłą formą ekspresji ludzkiej, uwarunkowaną historycznie i przemijającą... ${ }^{27}$.

Zanikanie ,religijnego a priori” Bonhoeffer wiązał nie tyle z tradycją oświeceniową w szerokim sensie, racjonalizującą świat i ujawniającą antropologiczne uwarunkowania religii, ile przede wszystkim ze społecznym procesem emancypacji. Innymi słowy, powodem przemijania religii jest nie tyle jej teoretyczna krytyka, ile praktyka społeczna - zmiana świadomości społecznej w wyniku ewolucyjnego procesu emancypacji i upodmiotowienia człowieka. Zdaniem Bonhoeffera, człowiek i świat stają się coraz bardziej dojrzali, a dojrzałość i autonomia nie wymagają już tradycyjnej transcendencji. Aby radzić sobie z życiem, dojrzały i autonomiczny człowiek nie musi poszukiwać magicznego wsparcia w zaświatach. Tego procesu, jak stwierdził autor listów i zapisków więziennych, nie można zanegować, on jest faktem. Z tego też względu atak chrześcijańskiej apologetyki na dojrzałość świata uznał za bezsensowny, niechrześcijański i właściwie nie do przeprowadzenia $^{28}$.

W duchu tradycji reformacyjnej Bonhoeffer był przekonany, że jedyną droga prowadzącą do doświadczenia Boga jest jego objawienie w Jezusie Chrystusie, które swoją pełnię zyskało w tym, co wydarzyło się na krzyżu Golgoty. Nie oznacza to jednak, że Boże objawienie zostało ograniczone do okresu ziemskiego życia Jezusa Chrystusa, a tym samym - jak to określał Soøeren Kierkegaard - do uczniów z pierwszej ręki. Doświadczenie Boga jest także i teraz możliwe, wszak Bóg uobecnia się w świecie w chrystologicznej postaci. We wczesnych pracach Bonhoeffera uobecniał się pod postacią „Chrystusa egzystującego jako zbór”, natomiast w listach i zapiskach więziennych - jako transcendencja etyczna. Bonhoeffer, nawiązując do ontologicznych przesłanek reformacyjnej teologii luterańskiej formułującej wykładnię sakramentu Wieczerzy Pańskiej przez analogię do chrystologii chalcedońskiej, był przekonany o tym, że skończoność może zawrzeć w sobie to, co nieskończone (finitum capax infiniti). W tym sensie obecność Boga

${ }^{27}$ Tamże, s. 403.

${ }^{28}$ Tamże, s. 478. 
jako Jezusa Chrystusa w świecie nie może mieć jedynie efemerycznego charakteru. Obecność ta przybiera konkretną postać - jest to Bóg w postaci ludzkiej. Bóg nie objawia się w rzeczach absolutnych, lecz „w naturalnej postaci człowieka"29. On objawia się jako transcendencja etyczna w spotkaniu człowieka, naśladującego Chrystusa, z drugim człowiekiem.

Postulatowi naśladowania Bonhoeffer poświęcił odrębną książkę, pisaną w okresie swojej pracy w seminarium kaznodziejskim w Finkenwalde. W tym miejscu ograniczymy rozważania wyłącznie do wywodów zawartych w listach i zapiskach więziennych. Jezus Chrystus stanowił dla Bonhoeffera przykład życia w miłości i odpowiedzialności, w całkowitym oddaniu i poświęceniu się dla dobra człowieka, w swoistym zastępowaniu tych, którzy nie mogli sprostać wyzwaniom życia (etos zastępowania bądź substytucji). Jezus Chrystus był tym samym wzorem nowego sposobu egzystowania w świecie. Fenomenologia owego sposobu bytowania w świecie prowadziła do ukazania jego podstawowej, elementarnej, a zarazem uniwersalnej charakterystyki, którą jest „bycie-dla-innych” (Dasein-für-andere). Z perspektywy filozoficznej należy w tym miejscu wspomnieć o związkach myśli Bonhoeffera z fenomenologiczną ontologią Martina Heideggera, czemu bezpośredni wyraz dał w swojej rozprawie habilitacyjnej Akt $i$ byt. Filozofia transcendentalna $i$ ontologia $w$ teologii systematycznej (1931). Ujęcie takie nie tylko pozwalało na zrozumienie działalności Mistrza z Nazaretu, lecz również implikowało tak samo brzmiący postulat etyczny: „być-dla-innych” (Für-andere-dasein). Owo „bycie-dla-innych” stało się pryncypium określającym życie i twórczość teologiczną Bonhoeffera, a w konsekwencji wyznacznikiem sposobu egzystowania chrześcijanina w świecie.

Nasza relacja do Boga nie jest odniesieniem religijnym do jakiejś dającej się pomyśleć, najwyższej, możnej i najlepszej istoty - to nie jest prawdziwa transcendencja. Nasza relacja do Boga jest nowym życiem w byciu-dla-innych, w uczestniczeniu w bycie Jezusa. Tym, co transcendentne, nie są jakieś nieskończone i nieosiagalne zadania, lecz konkretnie dany nam i osiagalny bliźni. Bóg w ludzkiej postaci! Nie jak w przypadku religii orientalnych pod postacią zwierząt jako coś ogromnego, chaotycznego, dalekiego, strasznego; także nie w formie pojęć tego, co absolutne, metafizyczne, nieskończone, etc.; także nie jako coś w rodzaju greckiej, bosko-ludzkiej postaci człowieka samego w sobie, lecz jako człowiek dla innych! I właśnie dlatego ukrzyżowany ${ }^{30}$.

\footnotetext{
${ }^{29}$ Tamże, s. 490.

30 Tamże, s. 558-559.
} 
Powyższy cytat pochodzi z zamieszczonego w Widerstand und Ergebung projektu przyszłej książki i implikuje, zgodnie z przekonaniem samego Bonhoeffera, określoną orientację hermeneutyczną. W nawiązaniu do tego cytatu czytamy: „Z tej perspektywy interpretacja pojęć biblijnych”. Z tego też względu idee bezreligijnego chrześcijaństwa i niereligijnej interpretacji pojęć biblijnych nie powinny być rozumiane w kategoriach teoretycznego projektu krytyki historycznej, dekonstrukcji czy egzegezy, lecz jako projekt odnowy chrześcijaństwa i języka teologii sytuujący ekspresję wiary w egzystencjalnej odpowiedzialności za kształt relacji Ja-Ty. Owo etyczne zaangażowanie jest zarazem szansą na doświadczenie spotkania, i to zarówno z Ty drugiego, jak i Ty samego Boga. ,Transcendencja Boga nie jest transcendencją naszych możliwości poznawczych. Transcendencja teoriopoznawcza nie ma nic wspólnego z transcendencją Boga. Bóg jest transcendentny w centrum naszego życia"31.

Konkludując można stwierdzić, że Bonhoeffer rozwinął dialogikę horyzontalną, i to zarówno w kategoriach antropologicznych, jak i teologicznych. Jego teologia była związana z doświadczeniem Ty w centrum tego świata. W opisach relacji między jednostką i wspólnotą, między jednostką i drugim człowiekiem, a wreszcie między jednostką i Bogiem wykorzystał pojęciowość charakterystyczną dla klasycznej filozofii dialogu. Specyfiką Bonhoeffera było natomiast włączenie do refleksji dialogicznej oryginalnie sformułowanej Dasein-analizy oraz egzystencjalnie i etycznie zorientowanej chrystologii. Istotnymi kategoriami relacji dialogicznej stało się , bycie-dla-innych” oraz doświadczenie transcendencji etycznej. Teologia Bonhoeffera markowała tym samym kierunek poszukiwań charakterystyczny dla współczesnej filozofii dialogu.

\subsection{Dialogika Dorothee Sölle}

W 1968 r. ukazał się zbiór esejów Sölle Ateistycznie wierzyć w Boga ${ }^{32}$. Był on swoistym manifestem etycznie zaangażowanej teologii protestanckiej. W eseju Teologia po śmierci Boga autorka rozpoczęła wywody od konstatacji współczesnej kondycji teologii protestanckiej. Po oświeceniu i jednocześnie $\mathrm{w}$ duchu reformacji teologia musi być nauką krytyczną, której przedmiotem jest nie tyle sam Bóg, ile wiara w Boga.

Gdyby przedmiotem teologii był jedynie Bóg, to zajmująca się nim nauka miałaby do czynienia wyłącznie z odtwarzaniem wieczystych prawd, a nie z krytyczną refleksją dotycząca powierzonej prawdy. Kto uprawia teologię, ten musi liczyć się także z możliwością, że wiara może być pomyłką. Teologia jest bo-

${ }^{31}$ Tamże, s. 408.

${ }^{32}$ D. Sölle, Atheistisch an Gott glauben, Olten 1968. 
wiem drogą do porozumienia w wierze i uprzednio nie może znać własnego bilansu. Ona stoi w poprzek tradycyjnie pozyskiwanej pobożności - specyfiką wiary chrześcijańskiej jest, że od okresu oświecenia nie może być już inaczej przeżywana. Watpienie, rezygnacja z własnej pozycji, gotowość do zmiany przynależą do wiary, o ile jest ona żywotna. Kto chce zachować własną wiarę,

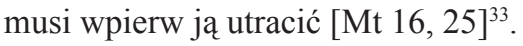

Na takiej drodze, zdaniem Sölle, fundamentalną rolę odgrywa doświadczenie, które Nietzsche określił mianem śmierci Boga. Bóg tradycyjnych wyobrażeń umarł, a śmierć zadał mu sam człowiek. Stąd też teologia powinna krytycznie przezwyciężać naiwność tradycyjnych doświadczeń. W tym zakresie Sölle szczególną rolę przypisała dokonaniom Friedricha Gogartena, Dietricha Bonhoeffera i Paula Tillicha. Swoją analizę stanu teologii po śmierci Boga rozpoczęła jednak od interpretacji diagnozy sformułowanej przez Hegla.

W procesie rozwoju w kierunku autonomii poszczególnych obszarów życia - polityki, moralności, gospodarki, prawa, wychowania - zachowujemy się często, et si deus non daretur [jak gdyby Boga nie było], jak to sformułował Grotius na początku siedemnastego wieku. O zniszczonej bezpośredniości Hegel pisał w Fenomenologii ducha: Jest to świadomość utraty ... substancji jaźni [jestestwa], jest to ból, który wypowiada się w postaci ostrego słowa: „Bóg umary"34.

W kontekście takiej diagnozy Sölle szukała nowych perspektyw uprawiania teologii. Doceniając wagę krytycznych opisów rzeczywistości wiary, ukazała ich fundamentalny problem. Opisy te, demaskując psychologiczne i społeczno-kulturowe aspekty wiary, bazowały na możliwości bezpośredniego doświadczenia Transcendencji. W miejsce a priori religijnego (religia jako oczywistość) ustanawiały a priori bezpośredniości spotkania z Bogiem - czy to w formie nieuwarunkowanej podstawy bytu (Tillich), eschatologicznego wezwania do decyzji (Bultmann) czy też pod postacią transcendentnego Ty (teologia dialektyczna). Zdaniem Sölle, sytuacja ,po śmierci Boga" jest bardziej skomplikowana. Krytyczne odrzucenie apriorycznego charakteru tradycyjnych wyobrażeń religijnych nie może zostać zastąpione oparciem teologii na kolejnym pewniku - na bezpośrednim doświadczeniu Boga. Teologia Sölle jest więc formą problematyzacji owej bezpośredniości dokonywaną m.in. w duchu nowego odczytania idealizmu niemieckiego,

\footnotetext{
33 Tamże, s. 52.

34 Tamże, s. 55.
} 
zwłaszcza filozofii Hegla. „To, że Boga nie ma już więcej, nie oznacza nic innego, jak tylko to, że nie ma go w sposób jednoznaczny"35.

W takim ujęciu ateizm i teizm przestają być alternatywą. Wiarygodny teizm zawiera bowiem w sobie krytyczny ateizm. Zdaniem Sölle, napięcie to można dostrzec nie tyle na poziomie metafizyki, ile dramatu ludzkiego istnienia. Wiarę można bowiem uprawomocnić tylko w konfrontacji z faktyczną egzystencją konkretnych osób i ich międzyludzkich relacji.

Teologia po śmierci Boga będzie próbowała opisać rezygnację Boga. Nie rozpłynie się przy tym w antropologii, jak mniemaja jej przeciwnicy, ale będzie uprawiać antropologię jako chrystologię, gdyż Bóg wydarza się między ludźmi w 'tym, co mi uczyniliście'. W pozbawionych wyrazu twarzach przedstawicieli ateizmu teologia taka na nowo rozpozna celników - przyjaciół Jezusa, i dostrzeże ich skrywaną samotność jako nowe możliwości, które dotąd nie były doświadczane, odkrywane i nie stanowiły przedmiotu społecznych pytań. Jej tematem będzie człowiek, który w sposób niezrozumiały został obrabowany ze swoich możliwości, a namysł na nim będzie koniec końców wypowiedzią o Bogu. O Bogu nie można mówić jedynie w czasie przeszłym [...]. Jego skrytość - najgłębsza podstawa naszego nihilizmu - otwiera nas na to, czego najbardziej od niego potrzebujemy: jego przyszłośćc ${ }^{36}$.

W tytułowym dla książki eseju Ateistycznie wierzyć w Boga Sölle opisała rozwój chrześcijaństwa w kategoriach desakralizacji rzeczywistości i jej nowego, etycznego odczytania. Chrześcijaństwo, a zwłaszcza protestantyzm, jest przykładem przekształcenia wiary metafizycznej w jej zsekularyzowaną realizację. W tym kontekście Sölle zadała fundamentalne pytanie o uprawomocnienie tak rozumianego chrześcijaństwa. Bo czymże zsekularyzowane i zorientowane etycznie chrześcijaństwo miałoby się różnić od humanizmu?

Bóg nie stał się mocą bądź ideą, ponadświatowym wybawicielem, treścią wiary, formą wynagrodzenia za osiagnięcia czy też zadośćuczynieniem za szkody, lecz stał się człowiekiem. Od tego momentu rozumienie człowieka i tego, co go dotyczy, a więc antropologii i etyki, nie może być zdefiniowane ostatecznie; dlatego wszelkie banalizujące uogólnienia jakobyśmy znali, czym jest dobro teraz i wiecznie, bądź też jakby nie istniał spór dotyczący tego, kim jest człowiek, stają się bezbożną gadaniną, która ciągle nie chce uznać jednej przesłanki: że oblicze Boga jest do rozpoznania tylko jako twarz drugiego obok mnie ${ }^{37}$.

\footnotetext{
35 Tamże, s. 73.

36 Tamże, s. 75-76.

37 Tamże, s. 87.
} 
Konkludując można stwierdzić, że w ujęciu Sölle dialogiczność ma wymiar horyzontalny i etyczny. Ów etos nie jest jednak dogmatyczny, czego dowodzi ostatni cytat, lecz jest formą odpowiedzialności egzystencjalnej za kształt relacji międzyludzkich, realizowanej w dokonywanych wyborach etycznych w obliczu drugiego człowieka. Teologii po śmierci Boga nie można jednak sprowadzić do humanizmu bez Boga. Jest to o wiele bardziej humanizm, podobnie jak u Bonhoeffera, ,jak gdyby Boga nie było, ale przed Bogiem”. Po pierwsze, Bóg daje się poznać w etycznym zaangażowaniu człowieka na rzecz drugiego człowieka. Nie jest to jednak doświadczenie bezpośrednie. Oblicze Boga nie ukazuje się bowiem w sposób absolutny i bezpośredni, ale jest doświadczane w twarzy drugiego człowieka. Takie ujęcie zakłada i zarazem legitymizuje krytyczność i wątpienie. Po drugie, istotą myśli Sölle jest egzystencjalnie i etycznie odczytana chrystologia. Jej podstawowym wyznacznikiem jest symbol krzyża.

Najdokładniejszą interpretację egzystencji ludzkiej, którą znam i która się dla mnie potwierdziła, jest krzyż Chrystusa. [...] W życiu i śmierci Jezusa możemy rozpoznać, jak może wyglądać życie ludzkie. Czyż prawdą, jedynym sensem egzystencji nie jest to, co się w wyraża w krzyżu Jezusa: bezwarunkowa miłość do drugiego człowieka, prowadząca do oddania własnego życia? ${ }^{38}$

\section{Pedagogiczna recepcja myśli dialogicznej}

Teologia i filozofia dialogu miała wpływ na rozwój protestanckiej pedagogiki religii. Był to jednak wpływ ograniczony. Dotyczył on przede wszystkim recepcji dokonań teologii dialektycznej i promowanej przez nią dialogiki wertykalnej, co przyczyniło się do sformułowania w latach 30 . XX w. koncepcji pedagogii kościelnej alternatywnej wobec pedagogii humanistycznej. Pedagogia kościelna była w istocie postacią antypedagogiki legitymizowanej poglądami teologicznymi. Wpływ dialogiki horyzontalnej zaznaczył się w latach 50. XX w. i przyczynił się do uwrażliwienia protestanckiej refleksji pedagogicznej na nową sytuację społeczną, której wyznacznikiem stał się z jednej strony problem odpowiedzialności chrześcijańskiej za kształt tego świata, co było szczególnie istotne w kontekście pamięci wojny, z drugiej natomiast wyzwania związane z procesami sekularyzacji i emancypacji człowieka. Od drugiej połowy lat 50 . XX w. rozwój protestanckiej pedagogiki religii zaczęła wyznaczać hermeneutyka egzystencjalna, a następnie hermeneutyka symbolu, teorie curricularne (teorie przebiegu procesów

${ }^{38}$ Tamże, s. 88. 
uczenia się i nauczania) czy teoria krytyczna. Od tamtego okresu teologia i filozofia dialogu nie pełniła już więcej paradygmatycznej roli dla refleksji pedagogicznej środowisk protestanckich.

\subsection{Pedagogia kościelna: przykład protestanckiej antypedagogiki}

Koncepcja pedagogii kościelnej została sformułowana w okresie międzywojennym, jednak jej apogeum przypadło na pierwszą dekadę okresu po zakończeniu II wojny światowej. Podstawową inspiracją teoretyczną była teologia dialektyczna, natomiast przesłanką społeczno-polityczną - współodpowiedzialność Kościoła ewangelickiego w Niemczech za katastrofę chrześcijańskiej Europy. Prowadziło to do ponownego sformułowania zasad funkcjonowania Kościoła w społeczeństwie. Działalność Kościoła powinna mieć charakter suwerenny, wolny od interesów politycznych i ideologicznych, i jednocześnie krytyczny wobec polityki i ideologii. Poszukując podstawowego kryterium krytycznego osądu rzeczywistości, zwrócono się w kierunku instancji transcendującej ten świat, a mianowicie w kierunku Słowa Bożego. Podejście takie korespondowało z podstawową intencją teologii dialektycznej, która tym samym została uznana za teologiczną podstawę tożsamości Kościoła ewangelickiego. Podejście takie wiązało się także z koniecznością opracowania nowej koncepcji oddziaływań wychowawczych. Ich podstawową formą była edukacja religijna w szkole.

Prekursorem tej koncepcji był Gerhard Bohne, który w 1929 r. opublikował pracę Stowo Boże a nauczanie ${ }^{39}$. Ówczesna praktyka kształcenia religijnego, utożsamiając religię z obyczajowością i moralnością, sprowadziła ją do poziomu kultury, a więc rzeczywistości hotyzontalnej. W konsekwencji powyższego kryzys kultury musiał prowadzić do kryzysu religii. Stąd Bohne wysunął postulat dialektycznej neoorientacji teorii i praktyki kształcenia religijnego. Jego podstawowe zadanie polega na postawieniu człowieka, adekwatnie do jego możliwości społecznych i psychologiczno-rozwojowych (wymiar horyzontalny), w sytuacji decyzji przed Bogiem. Dokonuje się to przez ukazywanie możliwości i realności spotkania człowieka z Bogiem oraz wezwania go do wsłuchania się w Słowo Boże (wymiar wertykalny) ${ }^{40}$.

W kwestiach pedagogicznych zabrał głos również sam twórca teologii dialektycznej, a mianowicie Karl Barth. Działalności wychowawczej Bartha i pedagogicznym implikacjom jego teologii zostało poświęcone obszerne studium Jürgena Fangmeiera Wychowanie w poświadczaniu. Karol Barth

\footnotetext{
${ }^{39}$ G. Bohne, Das Wort Gottes und der Unterricht, Berlin 1964.

${ }^{40}$ Tamże, s. 131, 110.
} 
i pedagogika $(1964)^{41}$. Fangmeier, potwierdzając zaprezentowane przez nas relacyjne i egzystencjalne ujęcie człowieka w Liście do Rzymian ${ }^{42}$, podkreślił pedagogiczne znaczenie wykładów z etyki prowadzonych przez Bartha w semestrze letnim 1928 r. na uniwersytecie w Münster. Barth powiazzał w nim refleksję wertykalną z horyzontalna ${ }^{43}$. Problem wychowania jest problemem autorytetu. Fangmeier przytoczył i skomentował archiwalne zapiski z tego wykładu:

Gdzie jest mój bliźni? Pytanie to można sprowadzić do innego: Gdzie spotyka mnie autorytet? Powiązanie z drugim człowiekiem jako powiązanie z autorytetem? Tak! Powiązanie z autorytetem jako związanie z bliźnim jako poprzednikiem, świadkiem, nauczycielem zgodności czynów grzesznego człowieka z prawem, jako powiązanie z bliźnim, o ile bliźni ten przekazuje mandat Boży (właśnie dlatego w Kościele Chrystusa Mojżesz jest bliźnim) ${ }^{44}$.

W tym sensie autorytetem nie tyle jest drugi człowiek jako taki, ile jako ten, który przekazuje mandat Boży. Ostatecznym autorytetem jest bowiem Słowo Boże, a bliźni staje się ważny wychowawczo dzięki mocy owego autorytetu.

Barth w wykładzie z etyki wyprowadził refleksję pedagogiczną z tzw. trzeciego rozumienia prawa (perspektywa teologiczno-normatywna) oraz $\mathrm{z}$ analizy wychowania jako faktu egzystencjalnego, będącego przedmiotem doświadczenia. Teologia reformacyjna XVI w. dowodziła konieczności istnienia prawa, ukazując jego dwie podstawowe funkcje: teologiczną (tzw. usus legis theologicus) i polityczną (tzw. usus legis politicus). Z perspektywy teologicznej istnienie prawa uświadamia człowiekowi szanse wynikające z otwarcia się na Ewangelię, która jest uwalniającym Słowem skierowanym do człowieka, Słowem wolności i wybawienia, wykraczającym poza każdą regulację, natomiast $\mathrm{z}$ perspektywy politycznej istnienie prawa zapobiega chaosowi życia społecznego. Melanchton i Kalwin wskazali na jeszcze jedno znaczenie prawa, na trzecie jego wykorzystanie (tzw. tertius usus legis), którym jest wykorzystanie pedagogiczne (tzw. usus legis paedagogicus). Do tej koncepcji odwołał się Barth. Traktował on wychowanie w kategoriach tzw. urzędu wychowawczego, którego legitymizacją jest trzecia funkcja prawa - uczenie człowieka pokory, gdyż prawo uświadamia ludzką grzesz1964.

${ }^{41}$ J. Fangmeier, Erziehung in Zeugenschaft. Karl Barth und die Pädagogik, Zürich

42 Tamże, s. 43-95, zwłaszcza 68 i następne.

43 Tamże, s. 125-175.

44 Tamże, s. 133. 
ność, a zarazem jest wezwaniem do prowadzenia szlachetnego życia ${ }^{45}$. Teologiczny namysł Barth konfrontował z interpretacją wychowania jako faktu egzystencjalnego. Wychowanie należy bowiem analizować wychodząc od doświadczenia. $Z$ tej perspektywy wychowanie ma charakter wydarzenia, które stawia pod znakiem zapytania to, co zastane, ono jest z jednej strony doświadczeniem zewnętrznych oddziaływań, swoistej przemocy, a zarazem jego istotą jest samokształcenie. Odwołując się do teologicznego przekonania o oddaleniu człowieka od Boga i wynikającej stąd naturalnej niedoskonałości człowieka (koncepcja grzechu pierworodnego), Barth twierdził, że wychowanie jest nie tyle procesem odnowy życia i całościowej przemiany egzystencjalnej, ile formą korekty życiowej. Odnowa życia, biblijna metanoja może dokonać się wyłącznie dzięki ingerencji transcendentnego Ty. Wychowanie jako działalność w porządku doczesnym ma natomiast na celu korektę człowieka ${ }^{46}$. Korekta ta może dokonywać się jednak wyłącznie z perspektywy autorytetu wychowawczego - autorytetu Słowa Bożego poświadczanego przez bliźnich. W tym sensie pedagogia chrześcijańska stała się w ujęciu Bartha pedagogią, którą można realizować wyłącznie z perspektywy świadectwa Słowa. Jej naturalnym miejscem staje się więc wspólnota wierzących - Kościół. Pedagogia chrześcijańska jest więc pedagogią kościelną. Ujęcie takie ugruntowała teologia zaprezentowana przez Bartha w jego opus magnum - wielotomowej Dogmatyce kościelnej. Jego wyrazem była również rozprawa, w której przedstawił on sumę swoich poglądów pedagogicznych.

W 1938 r. Barth wydał niewielką książkę Ewangelia $i$ kształcenie ${ }^{47}$. Przeanalizował w niej związki pomiędzy pojęciami i ideami teologicznymi i pedagogicznymi. Twierdził, że pojęcie kształcenia odnosi się do zadania kształtowania człowieka zgodnie z jego konstytucją i ostatecznymi możliwościami. Pojęcie Ewangelii określa natomiast przekaz o Jezusie Chrystusie, nie tylko jako Bogu, lecz również jako prawdziwym człowieku - w tym sensie jako człowieku w pełni ukształtowanym i wykształconym. Z tego względu przekaz ewangeliczny ukazuje możliwości, sens i cel kształcenia, a zarazem - z perspektywy tego wzoru pedagogicznego - jest krytyczną alternatywą wobec wszystkich innych planów edukacyjnych. Odwołując się do przesłanek teologicznych, Barth stwierdził, iż Ewangelia sprzeciwia się każdemu projektowi kształcenia, który konstruowany jest na założeniu o samowystarczalności człowieka. A to oznacza, że Ewangelia zawiera pedagogię, której podstawą nie jest człowiek i jego możliwości, lecz jedynie Bóg.

\footnotetext{
45 Tamże, s. 134-135.

46 Tamże, s. 137-141.

${ }^{47}$ K. Barth, Evangelium und Bildung, Zürich 1938.
} 
Ewangelia jest tedy programem kształcenia i kształtowania każdego wierzącego w kierunku bycia nowym człowiekiem na kształt Chrystusa. W takim ujęciu źródłem pedagogiki kościelnej nie mogą być teorie pedagogiczne, lecz przekaz biblijny i jego wykładnia teologiczna. Źródłem wychowania staje się tym samym spotkanie ze Ewangelią, w której uobecnia się Ty Boga i która ukazuje nową wizję człowieczeństwa.

Konkludując poglądy pedagogiczne Bartha można stwierdzić, że wyróżnił on dwa rodzaje wychowania. Pierwsza postać wychowania realizuje się w relacjach międzyludzkich i ma charakter korekty egzystencjalnej, dokonującej się w konfrontacji z autorytetem Słowa Bożego. W takim ujęciu Ewangelia staje się miarą człowieczeństwa i kryterium korekty. Drugi rodzaj wychowania jest wynikiem spotkania człowieka z samym Bogiem ukazującym się w Słowie. Dopiero spotkanie tego typu umożliwia przemianę egzystencjalną, stawanie się nowym człowiekiem, kształtowanym na wzór Chrystusa. W obu wypadkach miejscem realizacji pedagogii, której konstytutywnymi elementami są świadectwo o autorytecie i objawienie owego autorytetu, jest wspólnota ludzi wiary - Kościół. Co więcej, Barth uznawał totalność roszczenia teologicznego prawdy Ewangelii wobec całej rzeczywistości. Jego pedagogia była więc w istocie pedagogią kościelną której wyłącznym kryterium normatywnym stała się odpowiedzialność teologiczna. $\mathrm{Z}$ założenia była to koncepcja alternatywna wobec pedagogii i pedagogiki humanistycznej.

Pedagogia kościelna swoje apogeum osiagnęła w Niemczech w pierwszej dekadzie powojennej. Stała się ona podstawą nowej koncepcji edukacji religijnej, zwanej nauczaniem (instruktarzem) ewangelickim, wpisującej się w nurt tradycji kerygmatycznej. Dążąc do podporządkowania procesu wychowawczego wyłącznie normatywności teologicznej, nauczanie ewangelickie (Evangelische Unterrweisung) miało zerwać z dotychczasową praktyką nauczania religii ewangelickiej (Evangelischer Religionsunterricht). W nauczaniu ewangelickim chodzi bowiem o wiarę i Ewangelię, a nie o religię jako produkt ludzkiej duchowości i przedmiot polityczno-ideologicznej manipulacji. Głównymi przedstawicielami tego nurtu stali się Helmut Kittel i Oskar Hammelsbeck.

W 1947 r. ukazała się programowa rozprawa Kittel'a Od nauczania religii do nauczania ewangelickiego. Pierwszy rozdział nosił znamienny tytuł: Nigdy więcej nauki religii ${ }^{48}$. Prawda o wyzwoleniu człowieka jest zawarta $\mathrm{w}$ Ewangelii i tylko ona może stanowić skuteczną przeciwwagę wobec wszystkich nowych ideologii. Dlatego też należy zawiesić dotychczasowe

${ }^{48}$ H. Kittel, Vom Religionsunterricht zur evangelischen Unterweisung, WolfenbüttelHannover 1947. 
utożsamianie chrześcijaństwa z religią, a w konsekwencji zastąpić nauczanie religii nauczaniem ewangelickim. Prawdziwe wychowanie jest bowiem w istocie nauką wsłuchania się w głoszoną Ewangelię (kerygmat). Dlatego też podstawowe miejsce w kształceniu tego typu zajmuje Biblia, będąca nie tyle dokumentem historycznym bądź zbiorem teorii religijnych czy moralnych, ile przede wszystkim Objawieniem Boga.

Z dzisiejszej perspektywy można stwierdzić, że ujęcie takie prowadziło do traktowania wychowania ewangelickiego jako praktyki z założenia antypedagogicznej, a koncepcji pedagogii kościelnej - jako formy antypedagogicznej teorii wychowania. Zdaniem zwolenników opisywanej koncepcji, prawdziwym nauczycielem nie jest bowiem wychowawca, a jedynie sam Bóg. Istotą relacji wychowawczej jest nie tyle spotkanie z Ty drugiego człowieka, ile z transcendentnym Ty samego Boga. W tym kontekście Hammelsbeck pisał, że wychowujemy, jakbyśmy nie wychowywali, a sukces osiagamy jedynie wtedy, gdy uczniowie wyznają na wzór biblijny: Wierzymy już nie dzięki twemu opowiadaniu, sami bowiem słyszeliśmy i wiemy, że Ten jest prawdziwie zbawicielem świata $(\mathrm{J} 4,42)^{49}$. Podstawową cechą pedagogii kościelnej było bowiem przekonanie, że pedagogika i jej metody natrafiają na granicę nieuwarunkowanego oddziaływania Boga w Słowie. Z tej perspektywy pedagogia kościelna podważa wszelkie roszczenia pedagogiki humanistycznej.

Zaprezentowany program pedagogiczny można traktować jako reakcję na czasy polityczno-ideologicznej indoktrynacji Kościoła i systemu oświatowego w Niemczech. Jednak po jego wprowadzeniu w życie okazało się, iż pedagogia wydziedziczona $\mathrm{z}$ humanistycznej refleksji o edukacji jest również czymś parcjalnym i jako taka nie jest w stanie formułować adekwatnych odpowiedzi na wyzwania związane z wychowaniem w społeczeństwie pluralistycznym. Nasilająca się krytyka pedagogii kościelnej doprowadziła do zmiany paradygmatu w myśleniu o kształceniu religijnym i do powstania nowoczesnej pedagogiki religii.

\subsection{Dialog we współczesnej protestanckiej pedagogice religii}

W latach 50. XX w. protestancka pedagogika religii dokonała reorientacji w kierunku teorii kształcenia opartej na hermeneutyce egzystencjalnej Martina Heideggera i Rudolfa Bultmanna. Zyskała tym samym uprawomocnienie filozoficzne i teologiczne, niezależne od myśli dialogicznej. Wspo-

${ }^{49}$ O. Hammelsbeck, Glaube und Unterweisung, w: K. Wegenast (red.), Religionspädagogik, t. 1: Der evangelische Weg, Darmstadt 1981, s. 188-194. 
mniany w poprzednim punkcie O. Hammelsbeck zmodyfikował własną pedagogikę, nadając jej wymiar personalistyczny i dialogiczny w znaczeniu dialogiki horyzontalnej. Punktem odniesienia dla tego przedsięwzięcia była teologia D. Bonhoeffera, w której refleksja dialogiczna zyskała wymiar etyczny i została powiązana z problematyką emancypacji człowieka, pluralizacji i sekularyzacji życia społecznego. W okresie tym ponownie nawiązano dialog pomiędzy teologią i pedagogika, co prowadziło do ukonstytuowania się nie tyle pedagogiki protestanckiej, ile - uznając suwerenność samej pedagogiki - do powstania pedagogiki uprawianej w odpowiedzialności protestanckiej (ewangelickiej). Jej główną postacią stała się protestancka pedagogika religii. Przedmiotem dyskusji była nie tylko nowa koncepcja kształcenia religijnego, lecz również idea szkoły chrześcijańskiej oraz relacja pomiędzy kształceniem w szkole publicznej a normatywnością chrześcijańską. W dyskusję zaangażowali się przedstawiciele ówczesnej pedagogiki humanistycznej, m.in. Otto Friedrich Bollnow oraz Andreas Flitner, syn Wilhelma Flitnera $^{50}$. Dzięki pracom Martina Stallmanna i Gerta Otto powstały pierwsze całościowe teorie kształcenia religijnego rozumianego jako forma kształcenia hermeneutycznego.

Podstawowym wyznacznikiem protestanckiej pedagogiki religii stało się uznanie normatywności pedagogicznej przy jednoczesnym zachowaniu odpowiedzialności wobec normatywności teologicznej. Takie podejście umożliwiło nie tylko recepcję najnowszych dyskusji w naukach o wychowaniu, lecz również samodzielne opracowywanie własnych koncepcji pedagogicznych w duchu nowoczesnej hermeneutyki pedagogicznej, teorii krytycznej, teorii komunikacji, idei wychowania międzykulturowego i obywatelskiego. We współczesnej pedagogice religii podkreśla się znaczenie dialogu i dialogicznego charakteru samego człowieka. W badaniu tych kwestii wykorzystuje się jednak na ogół inne paradygmaty myślowe aniżeli opisana w niniejszym przyczynku teologia i filozofia dialogu. Stwierdzenie to obrazuje jedynie generalną tendencję. Nie oznacza więc wyrugowania tradycji dialogicznej, a jedynie jej ograniczony wpływ na dyskurs współczesny.

W najnowszej debacie jedną z podstawowych kwestii stał się pluralizm jako kontekst wychowania i jako wyzwanie edukacyjne. Przyjęcie takiej perspektywy jest szansą na ożywienie zainteresowania myślą dialogiczną. Przykładem tego są dwie współczesne monografie pedagogicznoreligijne poświęcone dialogiczności: Thorstena Knautha Nauczanie religii i dialog $(1996)^{51}$ oraz Reinholda Boschki'ego Relacja jako główne pojęcie pedago-

${ }^{50}$ K. E. Nipkow, Bildung in einer pluralen Welt, t. 2: Religionspädagogik im Pluralismus, Gütersloh 1998, s. 72 i następne.

${ }^{51}$ M. Knauth, Religionsunterricht und Dialog. Empirische Untersuchungen, systema- 
giki religii $(2003)^{52}$. Pierwszy autor reprezentuje protestancką pedagogikę religii, drugi natomiast katolicka. $W$ obu pracach legitymizacji teoretycznej dostarczyła klasyczna filozofia dialogu. Filozofia ta pozwala bowiem uprawomocnić na najbardziej podstawowym poziomie uniwersalny sens kształcenia w kontekście wielości kulturowo-społecznej, bez konieczności odwoływania się do uzasadnień ideologicznych.

\section{Dialogue thinking in Protestant tradition (Summary)}

The genesis of the philosophy of dialogue is associated with the work of Jewish philosophers as Franz Rosenzweig and Martin Buber and also with Ferdinand Ebner from the catholic side. This paper focuses on the protestant tradition of dialogue thinking in philosophy, theology and at least in pedagogy. The Karl Barth's monograph Der Römerbrief (1919, the second edition 1922), which was the programme manifest of dialectical theology, had been published before I and Thou (1923) and the some other standard books. The author reconstructed two types of dialogue thinking patterns - the vertical and the horizontal dialogic. The first type led to the development of so called protestant church pedagogy. From the perspective of educational theory it was the kind of anti-pedagogical movement. Another type of dialogic based on the category of the ethical transcendence and described the "I and Thou" relationship in horizontal dimension. It concentrated on the phenomenology of "Thou-presence". The experience of this presence is not to be seen in the direct way. The "Thou-experience" appears as double meaning and involves continues afford of interpretation. The horizontal dialogic supplies the basis of the modern pedagogy of dialogue. This pedagogy builds the aspects of the general theory of religious and also of humanistic education. It can be used as a philosophical legitimisation of multicultural and ecumenical learning.

tische Überlegungen und didaktische Perspektiven eines Religionsunterrichts im Horizont religiöser und kultureller Pluralisierung, Münster, New York, München, Berlin 1996.

${ }^{52}$ R. Boschki, Beziehung als Leitbegriff der Religionspädagogik: Grundlegung einer dialogisch-kreativen Religionsdidaktik, Ostfildern 2003. 
